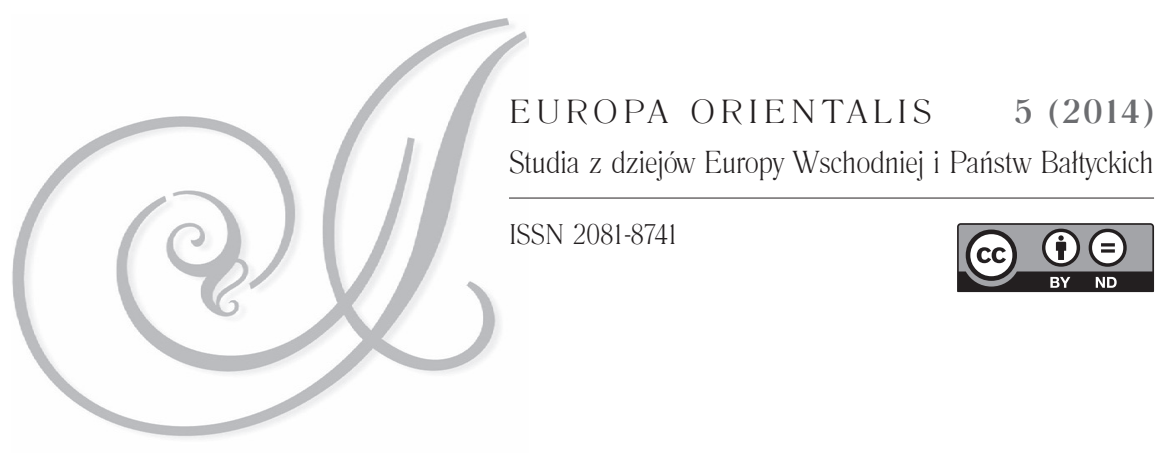

DOI: http://dx.doi.org/10.12775/EO.2015.019

\title{
II Международная научно-практическая конференция «Реклама и коммуникации: история и современность» в Барнауле (Россия)
}

\и международная научно - практическая конференция «Реклама в Барнауле 29 сентября 2015 г. Конференция была организована кафедрами «История Отечества», «Реклама и связи с общественностью» Алтайского государственного технического университета им. И.И. Ползунова» (в дальнейшем АлтГТУ им. И. И. Ползунова) совместно с Главным управлением образования и молодёжной политики Алтайского края и Издательским домом «Алтапресс».

Председателем организационного комитета конференции являлся ректор АлтГТУ им. И. И. Ползунова профессор А. А. Ситников, в состав организационного комитета вошли декан гуманитарного факультета АлтГТУ им. И. И. Ползунова профессор А. Н. Дунец, профессор Университета Н. Коперника в Торуни (Польша) В. Резмер, ведущий специалист отдела по связям с религиозными объединениями ГУ «Управление по делам религий Восточно-Казахстанской области» Е. Т. Мейрбаев (Усть-Каменогорск, Казахстан), генеральный директор Издательского дома «Алтапресс» (Барнаул, Россия) Ю. П. Пургин, заведующая кафедрой «История Отечества» АлтГТУ им. И. И. Ползунова профессор И. Н. Никулина, доценты кафедры «Реклама и связи с общественностью» АлтГТУ им. И. И. Ползунова В. В. Дмитриев и Н. Г Павлова. 
В работе конференции приняли участие ученые, преподаватели, сотрудники музеев и библиотек, художники России (Барнаул, Красноярск), Казахстана (Астана, Усть - Каменогорск), Польши (Варшава, Торунь).

Работа конференции осуществлялась по двум направлениям:

Актуальные проблемы рекламы и связи с общественностью (1 секция).

Историко - культурные особенности сибирского общества (2 секция).

Материалы выступлений 1 секции затрагивали различные аспекты рекламной деятельности в фокусе её основных проблем, а также историю рекламы, её роль и значение в обществе. Практически все доклады вызывали живой интерес у слушателей. Результаты своих исследований представили:

доцент Е.А. Московкина «Танатологический дискурс современной рекламы»,

(Алтайская государственная академия культуры и искусства, Барнаул), доцент Т. Г. Утробина «Синергетическая парадигма в теории и практике», (Алтайская педагогическая академия, Барнаул), доцент Л. Н. Лихацкая и заместитель директора Государственного художественного музея Алтайского края Н. С. Царева «Проект «Солнечные краски Италии» в Государственном,

художественном музее Алтайского края как пример межкультурной коммуникации» (АлтГТУ им. И. И. Ползунова, Государственный художественный музей Алтайского края, Барнаул), доцент Н. Г. Павлова «Образы Олимпиады-2014 в зеркале рекламы» (АлтГТУ им. И. И. Ползунова, Барнаул), доцент В. А. Черных «Польская реклама на Алтае» (АлтГТУ им. И. И. Ползунова, Барнаул). К сожалению, не все из запланированных сообщений были заслушаны на секции по причине болезни докладчиков.

В ходе работы II секции рассматривались историко - культурные особенности сибирского общества, во многом определившие становление и развитие рекламы в регионе, играющей в настоящее время все более заметную роль в жизни общества и являющейся частью массовой культуры.

Сложное географическое положение, большая удаленность от центральных территорий России, население, имевщее свои традиции и культурные особенности - все это определило специфику развития региона и сопредельных территорий. 
Тематика 15 выступлений на секции отражала различные стороны жизни сибирского общества, что свидетельствует о разнообразии подходов и направлений исследований.

Особый интерес вызвали выступления профессора В. Резмера (Университет Н. Коперника, Торунь, Польша), показавщего имеющиеся в настоящее время знания и представления об Алтае в Польше, научного сотрудника И. В. Дурново, раскрывшей личность составителя «словаря русских личных имен Н. А. Петровского (Восточно-Казахстанский областной архитектурно-этнографический и природно-ландшафтный музей-заповедник, Усть-Каменогорск, Казахстан), научного сотрудника И. Б. Каланчиной, осветившей взаимосвязь русской и казахской литератур на примере творчества Абая (Центр краеведческой информации, Усть-Каменогорск, Казахстан), заместителя директора М. Н. Потупчик, подчеркнувшей роль книги в жизни сельских жителей Алтайского округа (конец XIX-начало XX вв.) (Алтайская краевая универсальная научная библиотека им. В. Я. Шишкова, Барнаул).

По ходу выступлений у присутствующих появилось много различных вопросов, в ряде случаев возникали основания для дискуссионных выступлений и обсуждений.

Приятным дополнением к работе конференции стала традиционная экспозиция работ в Центре культуры АлтГТУ им. И. И. Ползунова.

Все доклады участников конференции опубликованы в сборнике материалов, с которым могут ознакомиться все желающие. 